ČEDOMIR DUNDOVIĆ, Ph.D.

E-mail:dundovic@pfri.hr

University of Rijeka, Faculty of Maritime Studies

Studentska 2, HR-51000 Rijeka, Republic of Croatia

MIRKO BILIĆ, Ph.D.

E-mail: mbilic@pfst.hr

JOŠKO DVORNIK, Ph.D.

E-mail: josko@pfst.hr

University of Split, Faculty of Maritime Studies

Zrinsko-Frankopanska 38, HR-21000 Split,

Republic of Croatia

\title{
CONTRIBUTION TO THE DEVELOPMENT OF A SIMULATION MODEL FOR A SEAPORT IN SPECIFIC OPERATING CONDITIONS
}

\begin{abstract}
The purpose of this paper is to show the efficiency of application of system dynamic simulation modelling when researching the behaviour dynamics of the port transhipment process, and finding the optimal solution for cargo handling with regard to the type and scope of cargo traffic, directions of movement, and pace of receiving and shipping of cargo. In view of the potential scientific implementation and verification of the hypotheses about the usage of system dynamic simulation models, the goals are multi-dimensional as they include designing qualitative and quantitative simulation models for a non-linear system, verification of the validity of the behaviour dynamics of the model, application of the simulation models, application of the parameter optimisation of the simulated process, and scientific verification of the results obtained through the simulation of the model. In compliance with the developed system-dynamic, mental-verbal and structural model, using the Powersim Studio system-dynamic flowchart of the port cargo system, in Powersim Studio simulation language, it is possible to conduct a scientific research of the dynamics of the continuous behaviour of the observed port cargo system in an experimental way, i. e. by using computers, simulating various scenarios of likely occurrences in the real world, without jeopardising it.
\end{abstract}

\section{KEY WORDS}

system dynamics, modelling, transhipment process, optimisation, continued and discrete simulation

\section{INTRODUCTION}

The domination of a complex stochastic behaviour of port processes, particularly in transhipment of cargo, is a typical feature of the traffic role of the port system. The complexity of factors and the dyna- mism of transhipment processes require a complex system approach to defining the system of handling cargo operations in ports. Modern scientific and technological development has resulted in valuable methods and solutions which can be applied to the issues related to the management of cargo handling systems.

The very development of the system-dynamic simulation model for port transhipment processes has followed the development of the qualitative and quantitative models, i. e. the global simulation model for the port transhipment process, which the authors have presented in a number of publications and international scientific conferences [7-10], as well as in the doctoral dissertation of one of the authors [1].

Simulated scenarios assume various unplanned events that are supposed to have cause-effect impacts on the expected change of behaviour dynamics of the observed port system.

The basic model is presented by a structural model in Figure 1.

The mental-verbal model of the Port-Transshipment System:

Fundamentally, unloading of any kind of cargo can be divided into:

- ship arrival to the berthing position,

- unloading cargo from ship to shore,

- transport of cargo from the shore to the wagons, trucks and warehouses.

Unloading/loading of cargo in the port is a complex dynamics process with two subsystems:

- unloading/loading of cargo in the port,

- surrounding environment. 


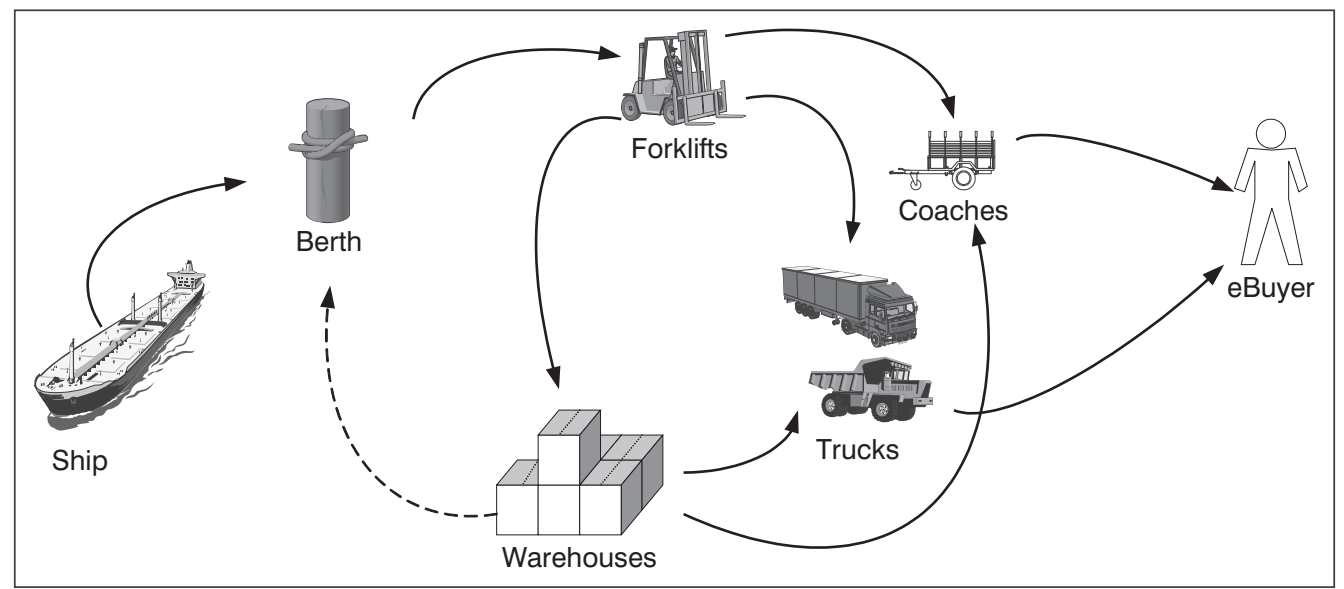

Figure 1 - Structural model for material flow of cargo

Source: J. Dvornik, A. Munitić, M. Bilić, Simulation modelling and heuristics optimization of material flow of the port cargo system

\section{DESCRIPTION OF THE OBSERVED SIMULATION PROCESSES}

The first scenario of the developed simulation model represents a scenario of the cargo discharge process, which is a realistic result of the continuous dynamic behaviour of the observed cargo flow over a period of time. By using historic data, i. e. data from the first scenario, it is possible to examine the validity of the set cause-effect relations and feed-back loops. The validity of the achieved expected behaviour results indicates that it is possible to apply the same model to various scenarios. In this way we have the possibility of designing quality forecasts for likely future situations, based on the condition changes and present state of the variables of the cargo discharge process [20, pp. 47-54].

\subsection{First scenario}

The first scenario has defined limiting conditions which are to be taken into account in order to achieve an uninterrupted discharge process, which is essential for achieving the minimum turn-round time.

The following limiting conditions have been defined:

- Overall tonnage of the ship's cargo to be discharged: $19,111 \mathrm{~m} / \mathrm{t}{ }^{1}$

- Availability of coach capacity amounts to 1000 tons every 24 hours;

- Availability of truck capacity amounts to 800 tons every 24 hours;

- Available port storage space, capable to receive the ship's cargo, amounts to 45,000 tons;

- Number of port cranes is 2;

- Single crane efficiency amounts to $50 \mathrm{t} / \mathrm{h}$;

- Number of forklifts is 2;

- Single forklift efficiency amounts to $50 \mathrm{t} / \mathrm{h}$;
- Number of tractor trailers for transporting cargo from the quay to the warehouse is 2 ;

- Single capacity of the port transhipment facility amounts to 50 tons.

When the ship is made fast to the berth/quay, the discharge operation can be started, provided that both the ship and the port are ready to start the discharge operation, and that all onboard administration procedures have been completed by the port authorities. The cargo is discharged onto the quay by means of two shore cranes whose combined efficiency amounts to $100 \mathrm{t} / \mathrm{h}$.

The cargo is then loaded by two forklifts having the overall efficiency of $100 \mathrm{t} / \mathrm{h}$ into the awaiting train of coaches of 1000 tons capacity, reserved 24 hours in advance. The coaches leave when they are loaded, and the loading resumes into the previously reserved trucks of 800 tons capacity. The cargo is loaded by the two forklifts that were used for loading the coaches. The trucks leave when they are loaded. At the moment when there are neither coaches nor trucks on the quay, the discharging operation does not stop; the forklifts load tractor trailers which transport the cargo to be temporarily stored in the port warehouse. The new stage of discharging operation starts with the arrival of a new train of coaches (reserved 24 hours in advance) and trucks (reserved 24 hours in advance). When they are loaded and gone, the cargo is stored in the warehouse. When the entire cargo is discharged from the ship and shipped out of the port, the remaining cargo is discharged from the port warehouse into coaches and trucks, until the warehouse is empty.

In normal port discharge processes, the port planner/manager has enough time to plan and book necessary facilities: cranes, forklifts, coaches, trucks and, if and when needed, storage space in the warehouses. The problems arise in the event of unplanned occurrences such as delays of transportation means, lack of available coaches or trucks, or perhaps, in the event 
of shortage of storage space, failure of a crane, malfunction of forklifts, and the like. This scenario actually represents a realised behaviour case of a transhipment system which has been handled until now by the manual intuitive logic of an experienced port manager. The intelligent logic of a planner/manager has been based on his long years' experience in managing port transhipment processes. Particular issues that port managers tackle include the optimal way of planning and optimising the necessary transporting facilities ashore, as well as ensuring temporarily available storage space in warehouses. The basic goal of any port planner/manager, and other participants who present links in the cargo transhipment chain, is "to ensure continuous process of transporting cargo from the ship to the quay in order to load the entire cargo into previously reserved coaches and trucks, storing it temporarily in the port warehouse if necessary, and ship the cargo to the client as soon as possible."

In order to carry out the optimal planning of the usage of a berth/landing place, it is necessary to foresee the total time of the berth's occupation, which will allow the port planner/manager to foresee the time of berthing, i. e. the starting transhipment time of the next ship, and to plan necessary transport and storage facilities in order to avoid any interruption during the discharge of the ship.

The total time of the berth's occupation can be presented by the following equation:

$\mathrm{T}_{\mathrm{uvzv}}=\mathrm{T}_{\mathrm{var}}+\mathrm{T}_{\mathrm{vib}}+\mathrm{T}_{\mathrm{vpob}}+\mathrm{T}_{\mathrm{vni}} \quad$ [hours]

where:

$\mathrm{T}_{\mathrm{uvzv}}$ - total time of the berth's occupation;

$\mathrm{T}_{\mathrm{var}}$ - time required for completing administration procedures upon the ship's arrival to the berth;

$\mathrm{T}_{\mathrm{vib}}$ - time needed for discharging the ship;

$\mathrm{T}_{\mathrm{vpob}}$ - time needed for preparations for leaving the berth;

$\mathrm{T}_{\mathrm{vni}}$ - time when there are no discharging operations (only the first and second shift working, holidays, etc.).

\subsection{Second scenario}

This scenario contains the same limiting conditions as the first scenario, except for the following conditions:

- there are $38,366.70 \mathrm{~m} / \mathrm{t}$ of cargo to be discharged from the ship;

- 5000 tons of cargo can be stored at the warehouse.

\subsection{Results of the computer simulation}

\subsubsection{Results of the first scenario}

According to the first scenario, the priorities in the process of discharging cargo from the ship and loading cargo into transport facilities ashore are given firstly to the coaches, then to the trucks, and eventually to the warehouse if there are no coaches and trucks available. The simulation has been carried out and the following results in tabular and graphic form have been obtained.

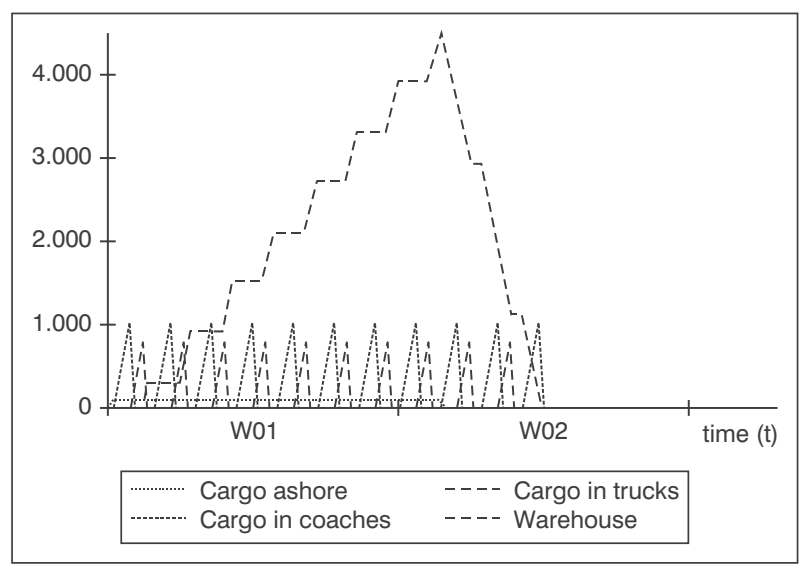

Figure 2 - Results of the first scenario

Table 1 displays the results of the first simulation scenario over a two-day period. It makes it possible to follow numeric values of the amount of cargo which are obtained over the observed period. In this way the performance in the given standardised environment can be controlled.

Table 1 - Tabular display of part of results of the first scenario

\begin{tabular}{|c|c|c|c|c|}
\hline $\begin{array}{c}\text { Hours } \\
\text { (Time) }\end{array}$ & $\begin{array}{c}\text { Discharge of } \\
\text { the ship }\end{array}$ & $\begin{array}{c}\text { Cargo in } \\
\text { coaches }\end{array}$ & $\begin{array}{c}\text { Cargo in } \\
\text { trucks }\end{array}$ & $\begin{array}{c}\text { Ware- } \\
\text { house }\end{array}$ \\
\hline \hline 0 & 0 & 0 & 0 & 0 \\
\hline 1 & 0 & 0 & 0 & 0 \\
\hline 2 & 100 & 0 & 0 & 0 \\
\hline 3 & 100 & 0 & 0 & 0 \\
\hline 4 & 100 & 100 & 0 & 0 \\
\hline 5 & 100 & 200 & 0 & 0 \\
\hline 6 & 100 & 300 & 0 & 0 \\
\hline 7 & 100 & 400 & 0 & 0 \\
\hline 8 & 100 & 500 & 0 & 0 \\
\hline 9 & 100 & 600 & 0 & 0 \\
\hline 10 & 100 & 700 & 0 & 0 \\
\hline 11 & 100 & 800 & 0 & 0 \\
\hline 12 & 100 & 900 & 0 & 0 \\
\hline
\end{tabular}


Table 1 - Tabular display of part of results of the first scenario (continued)

\begin{tabular}{||c|c|c|c|c||}
\hline $\begin{array}{c}\text { Hours } \\
\text { (Time) }\end{array}$ & $\begin{array}{c}\text { Discharge of } \\
\text { the ship }\end{array}$ & $\begin{array}{c}\text { Cargo in } \\
\text { coaches }\end{array}$ & $\begin{array}{c}\text { Cargo in } \\
\text { trucks }\end{array}$ & $\begin{array}{c}\text { Ware- } \\
\text { house }\end{array}$ \\
\hline 13 & 100 & 1000 & 0 & 0 \\
\hline 14 & 100 & 0 & 100 & 0 \\
\hline 15 & 100 & 0 & 200 & 0 \\
\hline 16 & 100 & 0 & 300 & 0 \\
\hline 17 & 100 & 0 & 400 & 0 \\
\hline 18 & 100 & 0 & 500 & 0 \\
\hline 19 & 100 & 0 & 600 & 0 \\
\hline 20 & 100 & 0 & 700 & 0 \\
\hline 21 & 100 & 0 & 800 & 0 \\
\hline 22 & 100 & 0 & 0 & 100 \\
\hline 23 & 100 & 0 & 0 & 200 \\
\hline 24 & 100 & 0 & 0 & 300 \\
\hline 25 & 100 & 100 & 0 & 300 \\
\hline 26 & 100 & 200 & 0 & 300 \\
\hline 27 & 100 & 300 & 0 & 300 \\
\hline 28 & 100 & 400 & 0 & 300 \\
\hline 29 & 100 & 500 & 0 & 300 \\
\hline 30 & 100 & 600 & 0 & 300 \\
\hline 31 & 100 & 700 & 0 & 300 \\
\hline 32 & 100 & 800 & 0 & 300 \\
\hline 33 & 100 & 900 & 0 & 300 \\
\hline 34 & 100 & 1000 & 0 & 300 \\
\hline 35 & 100 & 0 & 100 & 300 \\
\hline 36 & 100 & 0 & 200 & 300 \\
\hline 37 & 100 & 0 & 300 & 300 \\
\hline 38 & 100 & 0 & 400 & 300 \\
\hline 39 & 100 & 0 & 500 & 300 \\
\hline 40 & 100 & 0 & 600 & 300 \\
\hline 41 & 100 & 0 & 700 & 300 \\
\hline 42 & 100 & 0 & 800 & 300 \\
\hline 43 & 100 & 0 & 0 & 400 \\
\hline 44 & 100 & 0 & 0 & 500 \\
\hline 45 & 100 & 0 & 0 & 600 \\
\hline 46 & 100 & 0 & 0 & 700 \\
\hline 47 & 100 & 0 & 0 & 800 \\
\hline 48 & 100 & 0 & 0 & 900 \\
\hline
\end{tabular}

Upon ship's arrival to the berth, the ship's documents regarding the discharge of $19,111 \mathrm{~m} / \mathrm{t}$ of cargo were processed by the port authorities, all discharge facilities were ready, and the discharging operation started. During the second time unit $(\mathrm{TIME}=2)^{2} 100$ tons of cargo were discharged onto the quay.

During the first time unit (TIME=1), given the overall capacity/efficiency of two shore cranes and forklifts capable to handle $100 \mathrm{t} / \mathrm{h}$, the starting 100 tons of cargo were loaded into the coaches. After 13 time units (TIME=13), 1000 tons were discharged and shipped by the first train of coaches, leaving 18,011 tons on board. Meanwhile, the loading into trucks of 800 tons capacity began at the $14^{\text {th }}$ time unit $(\mathrm{TIME}=14)$. At the $21^{\text {st }}$ time unit $(\mathrm{TIME}=21)$ the loaded trucks left, leaving 17,211 tons on board. At the $22^{\text {nd }}$ time unit (TIME $=22$ ), given the fact that there were no coaches or trucks available, workers started transporting the cargo into the port warehouse in order to avoid the interruption of discharging the ship. By the $25^{\text {th }}$ time unit (TIME=25), 300 tons were stored in the warehouse. A new train of coaches of 1000 tons capacity arrived at the $25^{\text {th }}$ time unit and the loading started. After being loaded, the coaches left the port. Loading resumed at the $35^{\text {th }}$ time unit $($ TIME $=35$ ) upon the arrival of trucks of 800 tons capacity.

Due to the lack of coaches and trucks, from the $43^{\text {rd }}$ time unit $(\mathrm{TIME}=43)$ until the $48^{\text {th }}$ time unit (TIME $=48$ ), another 600 tons of cargo were transported to the warehouse, and the total of cargo stored there amounted to $900 t$. At that moment 14,611 tons remained onboard ship, waiting to be discharged.

From the $49^{\text {th }}$ time unit $(\mathrm{TIME}=49)$ to the $58^{\text {th }}$ time unit (TIME $=58)$ the cargo was loaded into a new train of coaches of 1000 tons capacity. Then the coaches left and the operation resumed by loading the trucks of 800 tons capacity until the $66^{\text {th }}$ time unit (TIME $=66$ ). After that, due to the lack of coaches and trucks, the cargo was transported into the warehouse until the $72^{\text {nd }}$ time unit $($ TIME $=72)$. At that point, the cargo stored at the warehouse totalled 1500 tons and there were still 12,211 tons of cargo waiting to be discharged from the ship. The cycle was repeated and at the $114^{\text {th }}$ time unit $($ TIME $=114)$ there were 8011 tons on board. The cargo was transported to the warehouse, totalling 2700 tons at that point of time, leaving 7411 tons onboard ship.

From the $121^{\text {st }}$ time unit $(\mathrm{TIME}=121)$ until the $138^{\text {th }}$ time unit (TIME $\left.=138\right)$, the coaches and trucks were loaded again. At the $138^{\text {th }}$ time unit $(\mathrm{TIME}=138)$ there were 5611 tons of cargo onboard ship, and the workers started again to transport the cargo into the warehouse. The total of cargo stored at the warehouse amounted to $3300 \mathrm{t}$. At the $144^{\text {th }}$ time unit (TIME =144), 5011 tons remained onboard ship. Following the once established dynamics, trains of coaches and trucks having the capacity of 1000 and 800 tons respectively, kept coming and the discharge 
of the ship was completed at the $194^{\text {th }}$ time unit (TIME =194). The total of 8000 tons was shipped by coaches and 6400 tons were shipped by trucks.

At the $194^{\text {th }}$ time unit $($ TIME $=194)$ there were 4500 tons of cargo at the warehouse. At the $195^{\text {th }}$ time unit (TIME=195), workers started discharging the cargo from the warehouse, first into trucks, then into coaches. This lasted until the $210^{\text {th }}$ time unit (TIME $=210)$, when the discharge was interrupted by the lack of coaches and trucks.

At that moment there were 2911 tons of cargo at the warehouse. The cycle of availability of coaches and trucks, having the capacity of 1000 and 800 tons respectively, was repeated according to the already established schedule of booking these capacities 24 hours in advance. The schedule of the cycle resulted in completing the discharge of the warehouse at the $253^{\text {rd }}$ time unit $(\mathrm{TIME}=253)$. By that time 3000 tons were conveyed by coaches, whereas 1711 tons were conveyed by trucks. The total time of discharging the warehouse consists of the time needed to load the cargo into coaches and trucks, and the time when there were no loading operations due to the lack of coaches and trucks. The total time of discharging the warehouse can be presented as follows:

$$
\mathrm{T}_{\text {ups }}=\mathrm{T}_{\text {evp }}+\mathrm{T}_{\mathrm{uvn}}[\text { hours] }
$$

where:

$\mathrm{T}_{\text {ups }}$ - total time of discharging the warehouse;

$\mathrm{T}_{\text {evp }}$ - effective time of discharging the warehouse;

$\mathrm{T}_{\mathrm{uvn}}$ - total time when the warehouse was not being discharged.

Using this first simulation model, it is possible to discharge the ship, in accordance with the given conditions, without interruptions during discharging.

\subsubsection{Results of the second scenario}

The discharge of the ship's cargo started by loading 1800 tons into coaches and trucks until the $19^{\text {th }}$ time unit $(\mathrm{TIME}=19)$. Due to the lack of coaches and trucks, 1800 tons of cargo were stored at the warehouse from the $20^{\text {th }}$ time unit $(\mathrm{TIME}=20)$ to the $37^{\text {th }}$ time unit. A new cycle of loading coaches and trucks started at the $38^{\text {th }}$ time unit (TIME $=38$ ) and ended at the $55^{\text {th }}$ time unit $($ TIME $=55)$. At the $56^{\text {th }}$ time unit (TIME $=56$ ), the cycle of loading the warehouse was repeated.

The warehouse was completely loaded with 5000 tons of cargo at the $104^{\text {th }}$ time unit (TIME=104). At that moment there were still $27,966.70$ tons onboard ship and an interruption of the discharge took place.

Upon the arrival of new coaches and trucks, the workers started discharging the warehouse, loading cargo into coaches, then into trucks. At the same time, the now available storage space at the warehouse was loaded with the ship's cargo, which means that the in- terruption of discharging was just temporary. Discharging the ship and loading the warehouse were carried out in cycles, with temporary interruptions.

At the $122^{\text {nd }}$ time unit (TIME $\left.=122\right) 100$ tons of cargo were discharged from the warehouse and loaded into coaches, then the ship's cargo was loaded into the remaining coaches and the newly arrived trucks. These cycles took place according to the established dynamics of the arrival of coaches and trucks, with the periodic loading of the warehouse to the maximum amount of 5000t, and temporary interruptions of the discharge of the ship.

The ship was entirely unloaded at the $384^{\text {th }}$ time unit (TIME =384). At that point of time there were 4900 tons in the warehouse. At the $402^{\text {nd }}$ time unit (TIME $=402$ ), workers started discharging the warehouse which was completely unloaded at the $449^{\text {th }}$ time unit (TIME=449).

The effective time needed for discharging the ship and the warehouse should be increased by the time of interruptions during the discharge of the ship and the warehouse, when new trains of coaches and trucks were awaited.

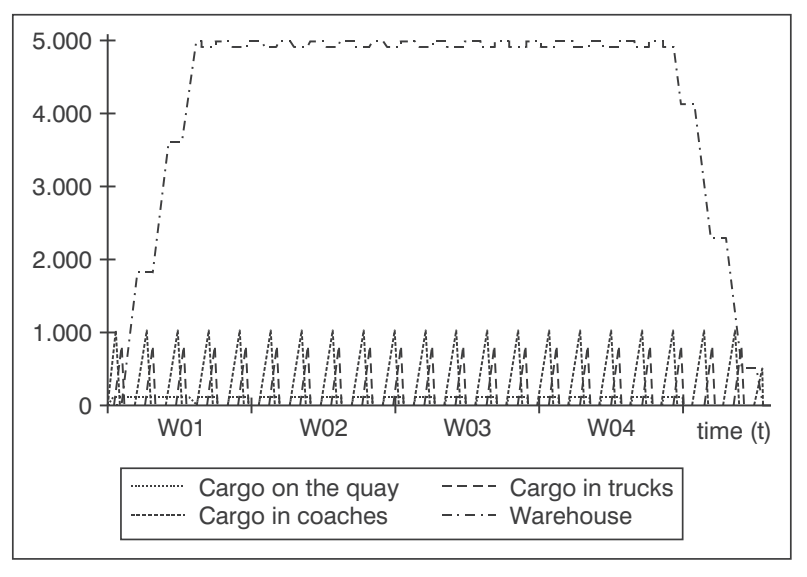

Figure 3 - Graphic display of the results of the second scenario

\section{CONTRIBUTION TO THE DEVELOPMENT OF A SIMULATION MODEL FOR A SEAPORT IN SPECIFIC OPERATING CONDITIONS}

In accordance with the obtained results, it is possible to apply various tonnages, types of cargo, cranes, trucks, coaches, forklifts, and storage space. It is particularly interesting to study the port manager's program module for the same cargo, but for different tonnage. It is possible to combine the number of shore cranes and ship derricks, and their capacities, with the arrival pace of coaches and trucks, as well as with the availability of forklifts and storage space. 
Using the zero scenario we have examined the basic scenario, whose results have confirmed the expected behaviour dynamics of the continuous discharge of cargo. Other scenarios have confirmed the same expected behaviours. Given the fact that the behaviour dynamics of all scenarios for this discharge model has been confirmed, it is rightfully believed that the application of such a model/planner is entirely justified when simulating the discharge of any type of ship. In addition to the scenarios presented in this paper, it is recommended that the practice includes additional analogue possible scenarios that are likely to appeal to the port manager. In other words, it is possible to apply this planner to examine the behaviour dynamics of entirely different cases of transhipment. Of course, this requires a suitable adaptation of the basic model.

The model provides an interesting possibility to examine the situation when cargo must be discharged from the ship and there are no storage and transport facilities ashore, whereas there is a possibility to unload cargo on the very quay along the ship, provided that the discharged cargo will not hinder any further handling when it is to be handled by forklifts and loaded into coaches and trucks, or conveyed into a suitable warehouse by means of tractor trailers or forklifts, and provided that the internal port communication is not obstructed. The simulation is particularly interesting for ports which do not feature large number of berths for the accommodation of certain types of ships and cargoes. It is also possible to apply the model to a number of berths in the way that the port planners apply several independent versions of the same model for a number of berths.

The model has been verified through the example of the Port of Šibenik, when $32,250.00 \mathrm{~m} / \mathrm{t}$ of ground crude phosphate were discharged from the ship Pakrac into the warehouse, then loaded and shipped by coaches, from $2^{\text {nd }}$ of September until $10^{\text {th }}$ September 2005 . The text that follows provides a description of all the verified elements of the observed system. The results of the research conducted in the Port of Šibenik, as well as the comparison with the obtained model results, are given in a tabular form.

\subsection{Port of Šibenik}

The port of Šibenik is situated in the middle part of the Adriatic Sea, at the mouth of the Krka River. It is a natural harbour, well protected from the waves. The port is approached through St. Ante Channel that allows the passage for ships up to 50,000 dwt. The port is linked with the hinterland by Šibenik - Knin railways which cotinues towards Zagreb, linking the port with the European railway system. The port is linked to Zagreb, Rijeka, Split, and other Croatian and European destinations by the Split - Zagreb motorway and the Adriatic Highway.
Due to the specialisation of the port facilities, the Port of Šibenik has become the major regional port for importing natural phosphates, handling 350,000 to 500,000 tons of cargo annually, covering the needs of chemical fertiliser industries in Kutina (formerly also covering the needs of Serbian industries in Subotica and Šabac), with prospects of handling 2,000,000 tons a year when construction of a modern terminal is completed. The terminal facilities for the transhipment of crude phosphate in the Port of Šibenik include an AB SIWERTELL ship unloader, conveyor belts, warehouses, two transhipment towers, loading station for loading coaches on two rail tracks, automatic weighing platform, and warehouse transhipment machinery with a scraper of $250 \mathrm{t} / \mathrm{h}$ capacity in the warehouse hall. The terminal is situated at the quay Dobrika (Figure 4), making use of natural conditions and previous construction works, necessary for setting a terminal for discharging crude ground phosphate.

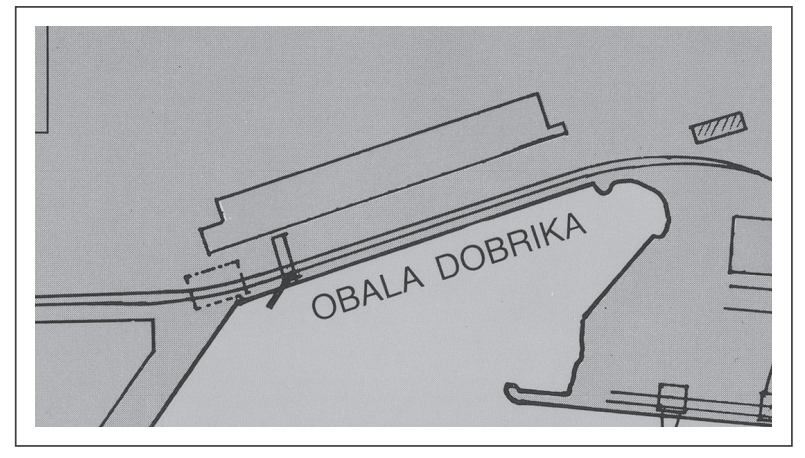

Figure 4 - Terminal for discharging crude phosphate in the Port of Šibenik

Source: M. Bilić, Optimizacija lučkih prekrcajnih procesa uporabom sistemske dinamike

Technical features of the Dobrika terminal:

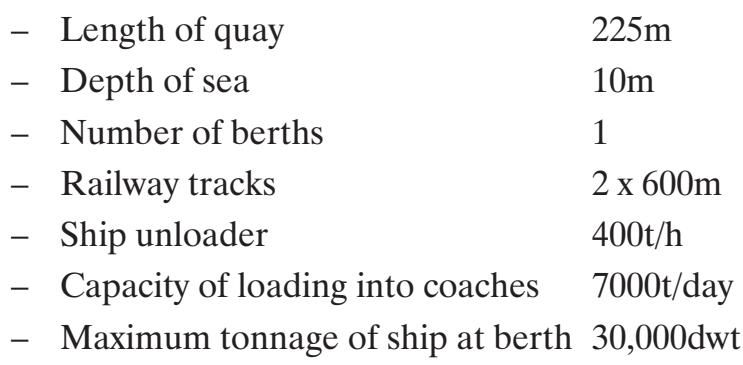

The overall terminal warehouse has a capacity of 105,000 tons. It is divided into six sections, five of them being able to store 15,000 tons, and the remaining section storing 30,000 tons of crude phosphate, so that six different types of phosphate can be stored at the same time. The warehouse capacity and all facilities are compatible with the local features, i. e. the filling angle for the representative sample of crude ground phosphate, type Togo 79/81, amounting to $32^{\circ}$. Given the fact that some sorts of phosphates have the filling angle of $34^{\circ}$, the arrangement of the warehouse and the scraper have been adjusted to the $34^{\circ}$ angle. 


\subsubsection{Description of the $\mathrm{m} / \mathrm{v}$ Pakrac}

The ship Pakrac, owned by the Zadar-based shipping company Tankerska plovidba plc., was built in the IHI shipyard, Yokohama (Japan) in 1978, for carrying dry bulk cargo.

The technical features of the ship are:

- Length overall (L) $187.73 \mathrm{~m}$

- Length between perpendiculars (Lpp)

$\begin{array}{ll}\text { - Beam (B) } & 178.00 \mathrm{~m} \\ \text { - Design draught } & 10.76 \mathrm{~m} \\ \text { - Breadth } & 28.40 \mathrm{~m} \\ \text { - Design height } & 15.30 \mathrm{~m} \\ \text { - Main engine - SULZER } & 7286 \mathrm{~kW} \\ \text { - Service speed } & 13.5 \mathrm{knots} \\ \text { - Tonnage (in five holds) } & 37,836 \mathrm{~m} / \mathrm{t}\end{array}$

\section{VALIDATION OF THE SIMULATION MODEL FOR DISCHARGING THE SHIP AND LOADING THE COACHES IN THE PORT OF ŠIBENIK}

According to the Bill of Lading, the ship Pakrac loaded $32,250 \mathrm{~m} / \mathrm{t}$ of crude phosphate in the port of Casablanca, Morocco for Petrokemija plc. - Kutina, Croatia. On $2^{\text {nd }}$ of September 2005, the ship docked at the berth Dobrika in the Port of Šibenik, handing over the Notice of Readiness and the Unloading Plan to the receivers. When the port authorities (customs, police, and the agent) completed all the procedures, the ship was granted Free Pratique and the second shift, starting working at 15,00 (3p. m.) started unloading the cargo. Referring to the Unloading Plan and the Notice of Readiness, the company Sibenik Ltd. started discharging the ship's hold $\mathrm{N}^{\circ} 3$ by means of a ship unloader.

Meanwhile, the workers started loading coaches with phosphate that had remained in the port warehouse (1000 tons) after the previous discharge of the ship. According to the contract between Luka Šibenik Ltd. and Petrokemija Plc. - Kutina, it was stipulated that a substantial portion of the phosphate cargo meant for Petrokemija plc. be temporarily stored at the port warehouse. As the company's own warehouse in Kutina did not have enough capacity, the cargo was loaded into coaches and shipped to the factory occasionally, according to the Petrokemija's technological needs, so that there were always certain amounts of old supplies at the port warehouse in Šibenik.

On the first day ( $2^{\text {nd }}$ of September), during the second and third shifts, 3671.57 tons were discharged from the ship and loaded into the warehouse. Meanwhile, during the second shift, 1868.00 tons of phosphate were loaded into 35 coaches.
On the second day, during the first, second, and third shifts, 8837.66 tons were discharged from the ship. During the first and second shifts 2990.60 tons were loaded into 58 coaches. By the end of the third shift there were 3979.06 tons of cargo at the warehouse.

On the third day of discharge, during the three shifts, 3816.75 tons were discharged, whereas 3364.20 tons were loaded into 63 coaches. By the end of the third shift the cargo in the warehouse amounted to 6069.61 tons.

On the fourth day, discharging was interrupted by rain from 14,30 to 18,50 - 4580.70 tons were discharged. During the first and the second shift 2611.10 tons were loaded into 49 coaches. Meanwhile, by the end of the third shift, there were 8039.21 tons in the warehouse.

On the fifth day, during the three shifts, 4685.91 tons of cargo were discharged from the ship, and the first and second shift workers loaded 961.90 tons into 18 coaches. There were 13,212.31 tons of cargo in the warehouse.

On the sixth day, during the first and second shifts, 2035.89 tons were discharged from the ship, and 586.80 tons were loaded into 11 coaches during the second shift. At the end of the second shift, there was the same quantity of cargo in the warehouse as it was on the fifth day of discharge, i. e. 13,212.31 tons, due to the failure of the unloader, so that the third shift did not work.

On the seventh day, the first and second shifts did not work because of the failure of the unloader. During the third shift 1098.59 tons of cargo were discharged but the coaches were not loaded.

On the eighth day, 4074.21 tons were discharged from the ship, whereas 1388.00 tons were loaded into 26 coaches during the first and the second shifts. By the end of the third shift the cargo in the warehouse amounted to $16,997.11$ tons of phosphate.

On the last day of discharge ( $10^{\text {th }}$ September), according to the Unloading Plan, the remaining cargo from the ship's holds was discharged and a total of 1482.29 tons of cargo was transported into the port warehouse. The loading of cargo into coaches was suspended as there were no demands from Petrokemija plc.

The Confirmation of discharge was issued to certify that the entire cargo was discharged from the ship.

The List of loaded coaches by shifts and the Train cargo list certified that a total of $13,770.60$ tons were shipped by means of coaches to Petrokemija plc. in Kutina, whereas the remaining 19,479.40 tons of cargo were stored at the port warehouse, awaiting further shipments, according to the needs of Petrokemija plc.

Before examining the validity of the results, it is important to point out that the development of the en- 


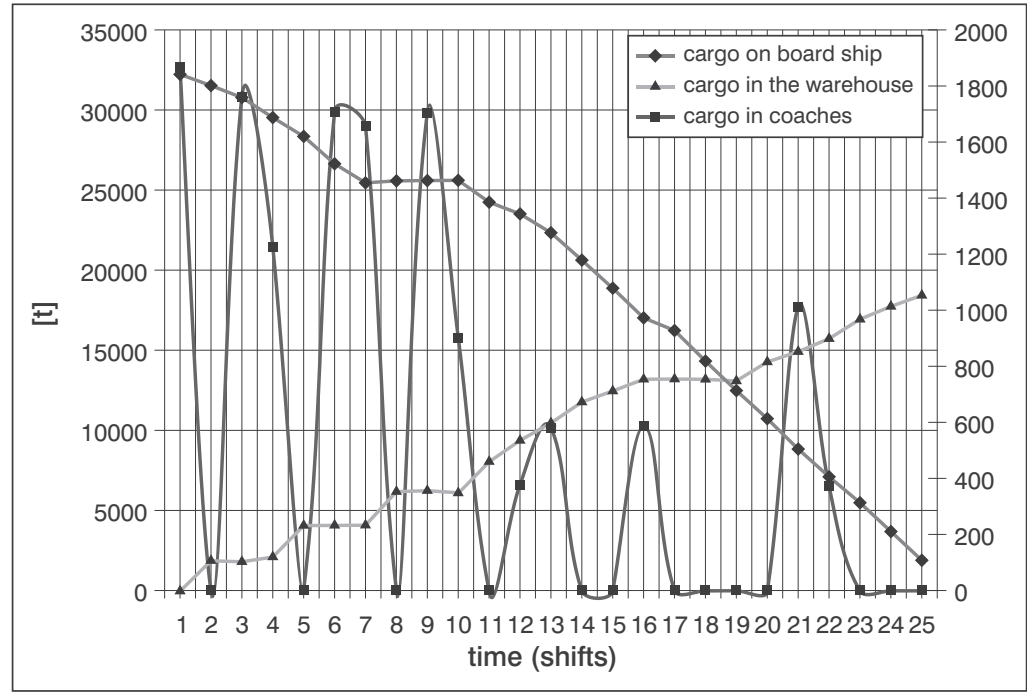

Figure 5 - Results of the validation of the simulation model for discharging the ship Pakrac, loading coaches, and the warehouse status

tire model has been based on the literature describing port system models that have been confirmed by experience. These models created the groundwork for the first modelling stage, i. e. the groundwork for the mental-verbal modelling. Owing to the insights into cause-effect activities, additional variables were determined, which, eventually, enabled the development of the mathematical-computer model that has been used in the presented scenarios. Therefore, one can assert that the conceptual model has been entirely harmonised with the requirements of the maritime science and profession, as well as the system dynamics, which allows for creating various likely scenarios.

Proving the validity of the developed model is based on the comparison of the results obtained by the simulation with the real results that were obtained by measuring, for each case separately. Introduction of this comparison into concrete practical cases would allow a dynamic observation of each port transhipment process under so-called unpredictable operating conditions that include failure of a crane, delay of trucks or trains, as well as extreme conditions resulting in a complete interruption of discharging the ship. Based on the results of sampling and the real results obtained in the model, displayed by graphs 5 and 6 , whose values as well as control points of loading coaches by shifts have turned out to be correct, it was proven that the model is valid and confirmed that the model has been behaving exactly according to the foreseen scenarios, which have been carried out and documented in practice, and which are presented in Table 2 and in the developed model of the initial and final state of discharging the ship Pakrac.

The results of the model are displayed in the graph whose correct values, as well as control points after shifts, can be read from the Table "Results of the validation of the simulation model for discharging the

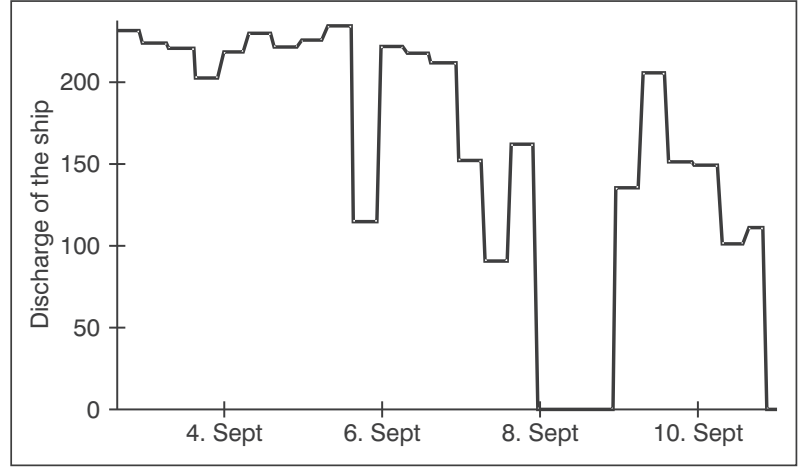

Figure 6 - Pace of discharging the ship Pakrac

ship Pakrac, loading coaches, and the warehouse status".

In this way the validation of the developed model for the Port of Šibenik on the occasion of discharging the ship Pakrac has been carried out. The actual behaviour dynamics of the model is very close to the likely behaviour in the real discharging process.

\section{CONCLUSION}

The management of a port transhipment system as a logistic function constantly tackles a number of complex issues, including the crucial ones such as the optimal choice of the transport technology and the optimisation of the exploitation of the means of transport. In theory, as well as in practice, there are numerous models for addressing these and similar issues.

The results presented in this paper are supposed to serve the basic objective: to contribute to the creation and development of the scientific-technical groundworks aiming at ensuring the sustainable development of local ports along the desired and planned profit. From the system point of view, the management of 
Č. Dundović et al.: Contribution to the Development of a Simulation Model for a Seaport in Specific Operating Conditions

Table 2 - Results of the process of cargo transhipment from the ship Pakrac into the warehouse and loading cargo into coaches

\begin{tabular}{|c|c|c|c|c|c|c|c|}
\hline \multicolumn{8}{|c|}{ Results of sampling the process of cargo transhipment } \\
\hline \multirow{2}{*}{\multicolumn{2}{|c|}{$\begin{array}{l}\text { Time of sampling, } \\
\text { (control points) }\end{array}$}} & \multicolumn{2}{|c|}{ State of discharged cargo } & \multicolumn{2}{|c|}{$\begin{array}{c}\text { State of cargo } \\
\text { loaded into coaches }\end{array}$} & \multicolumn{2}{|c|}{$\begin{array}{c}\text { State of cargo } \\
\text { at the warehouse }\end{array}$} \\
\hline & & by shifts & cumulative & by shifts & cumulative & by shifts & cumulative \\
\hline 2 Sept 2005 & 2nd shift & 1869.51 & 1869.51 & 1868 & 1868.00 & 1.51 & 1.51 \\
\hline 2 Sept 2005 & 3rd shift & 1802.06 & 3671.57 & 0 & 1868.00 & 1802.06 & 1803.57 \\
\hline 3 Sept 2005 & 1st shift & 1777.78 & 5449.35 & 1762.4 & 3630.40 & 15.38 & 1818.95 \\
\hline 3 Sept 2005 & 2nd shift & 1629.41 & 7078.76 & 1228.2 & 4858.60 & 401.21 & 2220.16 \\
\hline 3 Sept 2005 & 3rd shift & 1758.9 & 8837.66 & 0 & 4859.60 & 1758.9 & 3979.06 \\
\hline 4 Sept 2005 & 1st shift & 1850.62 & 10688.28 & 1708.3 & 6566.60 & 142.32 & 4121.38 \\
\hline 4 Sept 2005 & 2nd shift & 1783.18 & 12471.46 & 1655.9 & 8222.60 & 127.28 & 4248.66 \\
\hline 4 Sept 2005 & 3rd shift & 1820.95 & 14292.41 & 0 & 8222.80 & 1820.55 & 6069.61 \\
\hline 5 Sept 2005 & 1st shift & 1880.3 & 16172.71 & 1705.3 & 9928.10 & 175 & 6244.61 \\
\hline 5 Sept 2005 & 2nd shift & 917.22 & 17089.93 & 905.8 & 10833.90 & 11.42 & 6256.03 \\
\hline 5 Sept 2005 & 3rd shift & 1783.18 & 18873.11 & 0 & 10833.90 & 1783.18 & 8039.21 \\
\hline 6 Sept 2005 & 1st shift & 1745.41 & 20618.52 & 374.2 & 11208.10 & 1371.21 & 9410.42 \\
\hline 6 Sept 2005 & 2nd shift & 1704.95 & 22323.47 & 587.7 & 11795.80 & 1117.25 & 10527.67 \\
\hline 6 Sept 2005 & 3rd shift & 1235.55 & 23559.02 & 0 & 11795.80 & 1235.55 & 11763.22 \\
\hline 7 Sept 2005 & 1st shift & 730.2 & 24289.22 & 0 & 11795.80 & 730.2 & 12493.42 \\
\hline 7 Sept 2005 & 2nd shift & 1305.69 & 25594.91 & 586.0 & 12382.60 & 718.89 & 13212.31 \\
\hline 7 Sept 2005 & 3rd shift & 0 & 25594.91 & 0 & 12382.60 & 0 & 13212.31 \\
\hline 8 Sept 2005 & 1st shift & 0 & 25594.91 & 0 & 12382.60 & 0 & 13212.31 \\
\hline 8 Sept 2005 & 2nd shift & 0 & 25594.91 & 0 & 12382.60 & 0 & 13212.31 \\
\hline 8 Sept 2005 & 3rd shift & 1098.59 & 26693.50 & 0 & 12382.60 & 1098.59 & 14310.90 \\
\hline 9 Sept 2005 & 1st shift & 1656.39 & 28349.89 & 1014.1 & 13396.70 & 642.29 & 14953.19 \\
\hline 9 Sept 2005 & 2nd shift & 1213.97 & 29563.86 & 373.9 & 13770.60 & 840.07 & 15793.26 \\
\hline 9 Sept 2005 & 3rd shift & 1203.85 & 30767.71 & 0 & 13770.60 & 1203.85 & 16997.11 \\
\hline 10 Sept 2005 & 1st shift & 809.1 & 31576.81 & 0 & 13770.60 & 809.1 & 17806.21 \\
\hline 10 Sept 2005 & 2nd shift & 673.19 & 32250.00 & 0 & 13770.00 & 673.19 & 18479.40 \\
\hline
\end{tabular}

ports, in the broadest sense of the word, defines spatial and time merger of all relevant resources, needs and measures that have been used in an optimal way and enhanced by ports. The implementation of global, regional, and local objectives and priorities into the streams of management means steering the decision-making process towards the usage of modern scientific achievements and new technologies. When talking about new technologies, we primarily refer to the so-called system (management) scientific methods and tools which are based on, or are strongly related to, computer and information technologies.

This paper presents a system-dynamic simulation model for transhipment processes, compared with an empirical research conducted under real condi- tions. The practical application of this type of planning the necessary transport and discharge facilities allows a partial multiple professional behaviour of this model: apart from taking into consideration a number of limiting parameters, it changes decisions in a logical (intelligent) way and makes new ones during the discharge process, strictly taking care that no interruption takes place once the discharge is started.

Having examined this methodology in the Port of Šibenik, during the discharge of the ship Pakrac and the loading of coaches and the warehouse, it has been proved that this research methodology is very efficient in everyday practice. In other words, this scientific-research simulation method entirely justifies both the theoretical and practical application of the model to 
the management of transhipment processes and port as a whole.

\section{Dr. sc. ČEDOMIR DUNDOVIĆ}

E-mail: dundovic@pfri.hr

Sveučilište u Rijeci, Pomorski fakultet

Studentska 2, 51000 Rijeka, Republika Hrvatska

Dr. sc. MIRKO BILIĆ

E-mail: mbilic@pfst.hr

Dr. sc. JOŠKO DVORNIK

E-mail: josko@pfst.hr

Sveučilište u Splitu, Pomorski fakultet

Zrinsko-Frankopanska 38, 21000 Split, Republika Hrvatska

\section{SAŽETAK}

\section{DOPRINOS RAZVOJU SIMULACIJSKOG MODELA MORSKE LUKE U KONKRETNIM UVJETIMA RADA}

Svrha ovog rada jest pokazati uspješnost primjene sustavno dinamičkog simulacijskog modeliranja pri istraživanju dinamike ponašanja prekrcajnog procesa u luci te pronalaženja optimalnog rješenja prekrcaja s obzirom na vrstu i obim prometa tereta, pravce kretanja i dinamiku pristizanja i otpreme tereta.

Višedimenzionalna funkcija cilja, tj. ciljevi istraživanja dinamike ponašanja, s aspekta moguće znanstvene implementacije i verifikacije hipoteza o korištenju sustavno dinamičkih simulacijskih modela u su višestruki, te se ogledaju u izradi kvalitativnih $i$ kvantitativnih simulacijskih modela nelinearnog sustava, provjeri validnosti dinamike ponašanja modela, primjeni simulacijskih modela, primjeni optimizacije parametara simuliranog procesa, te znanstvenoj provjera dobivenih rezultata simulacije modela.

U skladu sa razvijenim sustavsko-dinamičkim: mentalno-verbalnim i strukturnim modelom, sustavsko-dinamičkim dijagramom tijekova u Powersim Studio simbolici sustava iskrcaja brodskog tereta u luci, u Powersim Studio programskom jeziku, moguće je eksperimentalno, tj. na računalu, znanstveno istraživati dinamiku kontinuiranog ponašanja promatranog sustava iskrcaja brodskog tereta u luci, simulirajući različite scenarije mogućih dogadanja u praksi, bez opasnosti po istraživani realitet.

\section{KLJUČNE RIJEČI}

sustavna dinamika, modeliranje, prekrcajni proces, optimizacija, kontinuirana i diskretna simulacija

\section{REFERENCES}

1. The abbreviation $\mathrm{m} / \mathrm{t}$ stands for metric ton $\left(1 \mathrm{~m} / \mathrm{t}=10^{3}\right.$ $\mathrm{kg}$ ).

2. TIME $=2$ stands for the zero time, i.e. the start of the time period.

\section{LITERATURE}

[1] Bilić, M.: Optimizacija lučkih prekrcajnih procesa uporabom sistemske dinamike, Sveučilište u Rijeci, Pomorski fakultet u Rijeci, doctoral dissertation, 2008
[2] Forrester, J. W.: Principles of Systems, MIT Press, Cambridge Massachusetts, USA, 1973/1971

[3] Munitić, A.: Application Possibilities of System Dynamics Modelling, System Dynamics, Edited by Susan Spencer and George Richardson, Proceedings of the SCS Western Multiconference, San Diego, California, A Society for Computer Simulation International, San Diego, USA, 1989, Munitić, A., "Computer Simulation with Help of System Dynamics”, Croatia, BIS, Split, p. 297, 1989

[4] Byrknes, A. H.: Run-Time User's Guide and Reference Manual, Powersim 2.5, Powersim Corporation, Powersim AS, 12007 Sunrise Valley Drive, Reston Virginia 22091 USA

[5] Zelenika, R., Jakomin, L.: Modern Transport Systems, in Croatian, Faculty of Economics - Rijeka, Croatia, 1995

[6] Richardson, George P. and Pugh III Aleksander L.: Introduction to System Dymanics Modelling with Dynamo, MIT Press, Cambridge, Massachusetts, USA, 1981

[7] Munitić, A., Bilić, M., Dvornik, J.: System Dynamics Simulation Model of the Port-Transhipments System, MITIP 2002, Savona, Italy, 2002, pp. 171-176

[8] Munitić, A., Bilić, M., Dvornik, J.: System Dynamics Simulation Model of the Port-Transhipments System, MEET/MARIND'2002, Varna, 2002, pp. 169-176

[9] Dvornik, J., Munitić, A., Bilić, M.: Simulation modelling and heuristics optimization of material flow of the port cargo system, Scientific journal on Traffic and transportation research, PROMET, ISSN 0353-5320, UDK 656, Vol. 18, 2006, No 2, pp. 123-135

[10] Munitić, A., Dvornik, J., Bilić, M.: Contribution to the investigation of the porttranshipment system using System Dynamics, $2^{\text {nd }}$ International Conference on Ports and Waterways, 5-6.10.2007, Vukovar, Croatia, ISBN 978-953-243-019-6, pp. 44-49

[11] Baričević H.: Tehnologija kopnenog prometa, Pomorski fakultet, Rijeka, 2001

[12] Buljan, I.: Prevoženje tereta morem, Društvo za proučavanje i unapređenje pomorstva, Zagreb, 1967

[13] Chopra, S., Meindl, P.: Supply Chain Management: Strategy, Planning, and Operation, Prentice-Hall, Inc. 2001

[14] Coyle, R. G.: System Dynamics Modeling, Capman \& Hall, London, 1996

[15] Čerić, V.: Simulacijsko modeliranje, Školska knjiga, Zagreb, 1993

[16] Čolić, V. et al.: Tehnologija rada pretovarno-transportnih sredstava u lukama i pristaništima, Univerzitet u Beogradu, Beograd, 1994

[17] Dundović, Č.: Lučki terminali, Pomorski fakultet, Rijeka, 2002

[18] Dundović, Č., Kesić, B.: Tehnologija i organizacija luka, Pomorski fakultet, Rijeka, 2001

[19] Dundović, Č.: Prekrcajna sredstva prekidnoga transporta, Pomorski fakultet, Rijeka, 2005

[20] Fox, B. E., Covington, W. W., Wood, D. B.: Integrating computer models for forest management, Proceedings of IUFRO Conference Forest Simulation Systems, Berkley, California, University of California, 1988 